\title{
Gambaran Persepsi Pasien terhadap Implementasi Pelayanan Kesehatan Selama Masa Pandemik COVID-19 di Wilayah Kota Depok Tahun 2020
}

\author{
Description of Patients' Perceptions of Health Service Implementation \\ during the COVID-19 Pandemic in Depok City in 2020
}

\author{
Alma Malika Idris ${ }^{1}$, Mustakim $^{1}$, Fini Fajrini' ${ }^{1}$, Noor Latifah $^{1}$ \\ ${ }^{1}$ Prodi Kesehatan Masyarakat, FKM Universitas Muhammadiyah Jakarta, Indonesia \\ *Korespondensi penulis: almalikaidris@gmail.com
}

Penyerahan: 17-06-2020, Perbaikan: 24-07-2020, Diterima: 23-09-2020

\begin{abstract}
Coronavirus Diseases 2019 (COVID-19) is a new type of disease that has never been previously identified in humans. COVID-19 cases in Indonesia until April 30, 2020 reached 10,118 cases with 792 deaths. The province with the highest number of COVID-19 cases was DKI Jakarta, reaching 4,175 cases with 371 deaths. Depok City is the city with the first COVID-19 patients in Indonesia and the trend of the development of COVID-19 infections in Depok City continues to increase every day, until 10 May 2020, 426 confirmed cases and 24 deaths. This research is a quantitative study with a cross sectional design with the number of respondents in the study, namely 107 samples. The data collection method uses a questionnaire through a questionnaire distribution in the form of google form. It was found that most of the respondents, namely $52.3 \%$, had the perception that the implementation of technical controls in health services was appropriate, most respondents, namely $63.6 \%$, had a perception that the implementation of administrative controls in health services was appropriate, and $55.1 \%$ have appropriate perceptions of the implementation of PPE in health services. Health services are expected to implement infection prevention and control programs consistently in accordance with the guidelines and to carry out continuous evaluation.
\end{abstract}

Keywords: Implementation of Health Services, Technical Control, Administrative Control, PPE.

\section{ABSTRAK}

Coronavirus Diseases 2019 (COVID-19) adalah penyakit jenis baru yang belum pernah diidentifikasi sebelumnya pada manusia. Virus penyebab COVID-19 dinamakan Sars-CoV2. Kasus COVID-19 di Indonesia hingga tanggal 30 April 2020 mencapai 10.118 kasus dengan kematian mencapai 792 jiwa. Provinsi kasus COVID-19 tertinggi yaitu DKI Jakarta mencapai 4.175 kasus dengan kematian 371 jiwa. Kota Depok merupakan kota dengan pasien COVID-19 pertama di Indonesia dan tren perkembangan infeksi COVID-19 di Kota Depok perhari terus meningkat, hingga tanggal 10 May 2020 terkonfirmasi mencapai 426 kasus dan kematian mencapai 24 jiwa. Penelitian ini adalah kuantitatif dengan desain penelitian cross sectional dengan jumlah responden dalam penelitian yaitu 107 sampel. Metode pegambilan data menggunakan kuesioner melalui sebaran angket dalam bentuk google form. Hasil Penelitian didapatkan bahwa sebagian besar responden yaitu 52,3\% memiliki persepsi bahwa implementasi pengendalian teknis di pelayanan kesehatan sudah sesuai, sebagian besar responden, yaitu 63,6\% memiliki persespi bahwa implementasi pengendalian administratif di pelayanan kesehatan sudah sesuai, dan 55,1\% memiliki persepsi sudah sesuai terhadap implementasi APD di pelayanan kesehatan. Bagi pelayanan kesehatan diharapkan dapat melaksanakan program pencegahan dan 
pengendalian infeksi secara konsisten sesuai dengan pedoman dan dilakukan evaluasi secara berkelanjutan.

Kata kunci: Implementasi Pelayanan Kesehatn, Pengendalian Teknis, Pengendalian Administratif, APD.

\section{PENDAHULUAN}

Coronavirus Diseases 2019 (COVID-19) adalah penyakit jenis baru yang belum pernah diidentifikasi sebelumnya pada manusia. Ada setidaknya dua jenis coronavirus yang diketahui menyebabkan penyakit infeksi saluran pernapasan yang dapat menimbulkan gejala berat seperti Middle East Respiratory Syndrome (MERS) dan Severe Acute Respiratory Syndrome (SARS). Virus penyebab COVID-19 dinamakan Sars-CoV-2. Virus corona adalah zoonosis (ditularkan antara hewan dan manusia). Penelitian menyebutkan bahwa SARS ditransmisikan dari kucing luwak (civet cats) ke manusia dan MERS dari unta ke manusia. Adapun, hewan yang menjadi sumber penularan COVID-19 ini masih belum diketahui (Kementerian Dalam Negeri, 2020). Coronavirus-19 (COVID) telah dinyatakan sebagai pandemik dunia oleh WHO (WHO, 2020). Virus dan penyakit ini diketahui berawal dari kota Wuhan, Cina sejak Desember 2019. Per tanggal 21 Maret 2020, jumlah kasus penyakit ini mencapai angka 275,469 jiwa yang tersebar di 166 negara, termasuk Indonesia (Kemenkes, 2020).

Dalam Al Quran surat Al-An'am ayat 103 ditegaskan secara qauliyah bahwa:

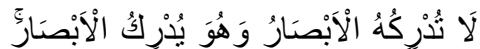

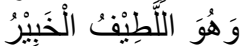

"Dia tidak dapat dicapai oleh penglihatan mata, sedang Dia dapat melihat segala penglihatan. Dan Dialah yang Maha Halus lagi Maha Mengetahui".
Artinya, secara kauniyah, dari COVID-19 ayat ini mengajarkan iman. Manusia tidak bisa melihat virus COVID-19 secara kasat mata, tapi manusia bisa merasakan dampaknya. Begitu juga dengan Tuhan, manusia tidak bisa melihat-Nya, tetapi kekuasaan-Nya selalu nyata, seperti virus COVID-19 yang diciptakan-Nya dalam ukuran sangat kecil itu juga kekuasaan-Nya yang nyata. Umat manusia harus selalu ingat dan percaya/iman kepada-Nya. Jangan karena Tuhan itu tidak kasat mata, lalu tidak dipercaya, padahal virus yang ekstra kecil itu juga tidak kasat mata, tapi manusia merasa takut dengan infeksinya.

COVID-19 menyebar dengan cepat ke seluruh dunia. WHO melaporkan pada tanggal 13 Maret 2020 kasus COVID-19 terdapat di 122 negara, dengan jumlah total 132.758 kasus terkonfirmasi dan 4.955 kematian (WHO, 2020). Karena banyaknya negara yang terjangkit, pada tanggal 12 Maret 2020 WHO meningkatkan status COVID-19 menjadi pandemi. Di Indonesia, COVID-19 pertama kali dilaporkan pada tanggal 2 Maret 2020 sebanyak 2 kasus, dan terus meningkat sampai pada tanggal 14 Maret 2020 jumlah kasus sebanyak 96 orang dengan 5 kematian (Kemenkes, 2020).

Data jumlah pasien COVID-19 di seluruh dunia hingga tanggal 30 April 2020 mencapai 3.090.445 kasus dengan kematian mencapai 217.769 jiwa. Lima Negara dengan kasus COVID-19 tertinggi yaitu United States of America (1.003.974), Iran (93.607), China (84.373), India (33.050) dan Arab Saudi (21.402). Negara dengan kasus kematian tertinggi di dunia yaitu 
United States of America (52.428), Italy (27.682), The United Kingdom (26.097), Spain (24.275) dan France (24.054) (WHO, 2020). Kasus COVID19 di Indonesia hingga tanggal 30 April 2020 mencapai 10.118 kasus dengan kematian mencapai 792 jiwa. Lima provinsi kasus COVID-19 tertinggi yaitu DKI Jakarta (4.175), Jawa Barat (1012), Jawa Timur (958), Jawa Tengah (724) dan Sulawesi Selatan (491). Provinsi dengan kasus kematian tertinggi yaitu DKI Jakarta (371), Jawa Timur (96), Jawa Barat (83), Jawa Tengah (59) dan Banten (41) jiwa (Kemenkes, 2020). Kota Depok merupakan kota dengan pasien COVID-19 pertama di Indonesia dan tren perkembangan infeksi COVID-19 di Kota Depok perhari terus meningkat, hingga tanggal 30 April 2020 terkonfirmasi 375 kasus dan kematian mencapai 21 jiwa. Hingga 10 Mei 2020 terkonfirmasi mencapai 426 kasus dan kematian mencapai 24 jiwa (Depok, 2020).

Presiden Republik Indonesia telah menyatakan status penyakit ini menjadi Tahap Tanggap Darurat pada tanggal 17 Maret 2020. Presiden juga telah mengeluarkan Keputusan Presiden No. 7 Tahun 2020 tentang Gugus Tugas Percepatan Penanganan Corona yang diketuai oleh Kepala Badan Nasional Penanggulangan Bencana (BNPB). Gugus Tugas ini bertujuan untuk meningkatkan ketahanan nasional di bidang kesehatan, mempercepat penanganan COVID-19 melalui sinergi antar kementerian/ lembaga dan pemerintah daerah, meningkatkan antisipasi perkembangan eskalasi penyebaran COVID-19, meningkatkan sinergi pengambilan kebijakan operasional, dan meningkatkan kesiapan dan kemampuan dalam mencegah, mendeteksi, dan merespons terhadap COVID-19 (Bnpb, Adisasmito, Guru, Fkm, \& Indonesia, 2020).
Berdasarkan bukti ilmiah, COVID-19 dapat menular dari manusia ke manusia melalui kontak erat dan droplet, tidak melalui udara. Orang yang paling berisiko tertular penyakit ini adalah orang yang kontak erat dengan pasien COVID-19 (Kemenkes, 2020). Petugas kesehatan berada di garis depan dari respons pandemi COVID-19 memiliki risiko yang lebih besar untuk terpajan infeksi (PERDOKI, 2020). Rekomendasi standar untuk mencegah penyebaran infeksi adalah melalui cuci tangan secara teratur, menerapkan etika batuk dan bersin, menghindari kontak dekat dengan siapapun yang menunjukkan gejala penyakit pernapasan seperti batuk dan bersin. Selain itu, penerapan Pencegahan dan Pengendalian Infeksi (PPI) saat berada di fasilitas layanan kesehatan (Kemenkes, 2020). Langkah terakhir adalah memperkokoh atap rumah besar kita. Atap rumah berfungsi melindungi para penghuni dari panas dan hujan. Dalam analogi ini atap tersebut adalah fasilitas pelayanan kesehatan yang bertugas melindungi rakyat dari kesakitan dan kematian.

Pembangunan

kesehatan

sebagai bagian dari pembangunan nasional mempunyai tujuan Nomor 36 Tahun 2009 tentang kesehatan pasal 5 menyebutkan bahwa setiap orang mempunyai hak dalam memperoleh pelayanan kesehatan yang aman, bermutu dan terjangkau. Berdasarkan latar belakang masalah diatas, penulis memandang penting untuk melakukan penelitian yang terfokus kepada implementasi pelayanan kesehatan di Wilayah Kota Depok dalam masa pandemik COVID-19 yang selanjutnya dituangkan dalam bentuk skripsi dengan judul "Gambaran Persepsi Pasien terhadap Implementasi Pelayanan Kesehatan selama masa Pandemik COVID-19 di Wilayah Kota Depok Tahun 2020". 


\section{METODE}

Metode penelitian ini adalah kuantitatif dengan desain penelitian deskriptif yang bertujuan untuk mengetahui gambaran persepsi pasien terhadap implementasi pelayanan kesehatan selama masa pandemik COVID-19 di Wilayah Kota Depok tahun 2020. Penelitian ini dilakukan Fasilitas Pelayanan Kesehatan Wilayah Kota Depok pada tanggal 28 Mei-16 Juni 2020. Sebelum dilakukan penelitian, kuesioner telah dilakukan uji validitas dan realibilitas dengan disebar kepada 30 responden yang diambil secara acak di daerah JABODETABEK menggunakan google form pada tanggal 17-22 April 2020.

Perhitungan besar sampel ditentukan dengan menggunakan rumus Lameshow (Riyanto et al, 2020) dan didapatkan jumlah sampel minimal yaitu 97 orang, kemudian untuk menghindari data missing maka ditambah $10 \%$, sehingga besar sampel dalam penelitian ini sebanyak 107 sampel. Responden akan ditentukan dengan teknik purposive sampling.

Analisis pada penelitian ini adalah univariat dengan menggunakan peneliti ingin melihat gambaran karakteristik responden seperti umur, jenis kelamin, pekerjaan, fasilitas pelayanan kesehatan yang terakhir dikunjungi dan variabel pengendalian teknis, pengendalian administratif dan alat pelindung diri dengan menggunakan skala likert.

\section{HASIL}

Tabel 1. Karakteristik Responden

\begin{tabular}{lcc}
\hline \multicolumn{1}{c}{ Variabel } & Jumlah & Persentase (\%) \\
\hline Jenis Kelamin & 26 & 24,3 \\
Laki-Laki & 81 & 75,7 \\
Perempuan & & \\
Umur & 97 & 90,7 \\
$12-25$ tahun & 8 & 7,5 \\
$28-45$ tahun & 2 & 1,9 \\
$46-65$ tahun & & \\
Pekerjaan & 59 & 55,1 \\
Pelajar/Mahasiswa & 2 & 1,9 \\
TNI/POLRI/BUMN & 32 & 29,9 \\
Pegawai Swasta & 2 & 1,9 \\
Guru/Dosen & 5 & 4,7 \\
Ibu Rumah Tangga & 3 & 2,8 \\
Belum/Tidak Bekerja & 4 & 3,7 \\
Yang Lainnya & & \\
Pelayanan Kesehatan & 33 & 30,8 \\
Puskesmas & 37 & 34,6 \\
Klinik & 37 & \\
Rumah Sakit & & \\
\hline
\end{tabular}

Berdasarkan Tabel 1. diatas dapat diketahui bahwa dari 107 responden yang diambil dalam penelitian mengenai persepsi pasien terhadap implementasi pelayanan kesehatan selama masa pandemik COVID-19 di Kota Depok, yaitu Laki- laki terdapat $26(24,3 \%)$ responden dan Perempuan terdapat $81(75,7 \%)$ responden, responden lebih banyak pada Perempuan. Berdasarkan tabel diatas dapat diketahui bahwa dari 107 responden yang diambil dalam penelitian mengenai persepsi pasien 
terhadap implementasi pelayanan kesehatan selama masa pandemik COVID-19 di Kota Depok, berdasarkan umur menunjukkan bahwa responden yang berumur 12 - 25 tahun berjumlah $97(90,7 \%)$, responden berumur 28 45 berjumalah $8(7,5 \%)$, dan responden berumur 46 - 65 tahun sebanyak 2 responden (1,9\%). Hal ini menunjukkan bahwa mayoritas responden pada umur 12 - 25 tahun. Berdasarkan tabel diatas dapat diketahui bahwa dari 107 responden yang diambil dalam penelitian mengenai persepsi pasien terhadap implementasi pelayanan kesehatan selama masa pandemik COVID-19 di Kota Depok terdapat $59 \quad(55,1 \%)$ responden yang merupakan pelajar/mahasiswa, sebanyak 2 $(1,9 \%)$ responden yang bekerja sebagai TNI/POLRI/BUMN, sebanyak $32(29,9 \%)$ responden yang pegawai swasta, sebanyak $2(1,9 \%)$ responden bekerja sebagai guru/dosen, sebanyak $5(4,7 \%)$ responden merupakan ibu rumah tangga, sebanyak $3(2,8 \%)$ yang belum/tidak bekerja, dan 4 $(3,7 \%)$ lainnya menyebutkan pekerjaan yang lain. Berdasarkan karakteristik pekerjaan responden menunjukkan bahwa sebagian besar responden merupakan pelajar/mahasiswa. Berdasarkan tabel diatas dapat diketahui bahwa dari 107 responden yang diambil dalam penelitian mengenai persepsi pasien terhadap implementasi pelayanan kesehatan selama masa pandemik COVID-19 di Kota Depok, berdasarkan pelayanan kesehatan yang dikunjungi oleh responden sebelum mengisi kuesioner, yaitu Puskesmas 33 (30,8\%) responden, Klinik 37 (34,6\%) responden, dan Rumah Sakit 37 $(34,6 \%)$.

\section{Persepsi Pencegahan dan Pengendalian Infeksi}

Tabel 2. Distribusi Persepsi Pasien terhadap Implementasi Pelayanan Kesehatan

\begin{tabular}{lccccc}
\hline \multicolumn{1}{c}{ Variabel } & Mean & Median & SD & Skewness & SE of Skewness \\
\hline Pengendalian Teknis & 12,99 & 13,00 & 2,284 & $-0,782$ & 0,234 \\
\hline $\begin{array}{l}\text { Pengendalian } \\
\text { Administratif }\end{array}$ & 13,25 & 13,00 & 2,088 & $-0,964$ & 0,234 \\
\hline Alat Pelindung Diri & 20,64 & 21,00 & 3,102 & $-0,758$ & 0,234 \\
\hline
\end{tabular}

Data tersebut diatas didapat dari hasil statistik pada distribusi jawaban responden yang ditampilkan pada Tabel 5.10, perhitungan menggunakan spss. Peneliti menggunakan cut of point untuk membuat kategori persepsi responden. Cut of point menggunakan median apabila data tidak terdistribusi normal. Penentuan data terdistribusi normal atau tidak dapat diketahui berdasarkan hasil perhitungan skewness dibagi dengan std error of skewness. Data dapat dikatakan terdistribusi normal jika hasil bagi skewness dengan std error $\leq 2$. Jika total skor yang diperoleh $\geq$ cut of point maka persepsi termasuk dalam kategori sesuai dan jika total skor yang diperoleh < cut of point maka persepsi termasuk dalam kategori kurang sesuai. 
Tabel 6. Distribusi Persepsi Pasien terhadap Implementasi Pelayanan Kesehatan

\begin{tabular}{lcc}
\hline \multicolumn{1}{c}{ Variabel } & Frekuensi & Persentase (\%) \\
\hline Pengendalian teknis & & \\
\hline Kurang Sesuai & 51 & 47,7 \\
\hline Sesuai & 56 & 52,3 \\
\hline Pengendalian Administratif & & \\
\hline Kurang Sesuai & 39 & 36,4 \\
\hline Sesuai & 68 & 63,6 \\
\hline Alat Pelindung Diri & & \\
\hline Kurang Sesuai & 48 & 34,9 \\
\hline Sesuai & 59 & 55,1
\end{tabular}

Dari data tersebut di atas maka diperoleh hasil bahwa sebanyak 51 responden mempunyai persepsi kurang sesuai terhadap implementasi pelayanan kesehatan dalam masa pandemik COVID-19 ditinjau dari pengendalian teknis $(47,7 \%)$. Sedangkan sebagian besar responden mempunyai gambaran persepsi sesuai terhadap implementasi pelayanan kesehatan dalam masa pandemik COVID-19 ditinjau dari pengendalian teknis, yaitu sebanyak 56 orang $(52,3 \%)$. Dari data tersebut di atas maka diperoleh hasil bahwa sebanyak 39 responden mempunyai persepsi kurang sesuai terhadap implementasi pelayanan kesehatan dalam masa pandemik COVID-19 ditinjau dari pengendalian administratif $(36,4 \%)$. Sedangkan sebagian besar responden mempunyai gambaran persepsi sesuai terhadap implementasi pelayanan kesehatan dalam masa pandemik COVID-19 ditinjau dari pengendalian administratif, yaitu 68 orang $(63,6 \%)$. Dari data tersebut di atas maka diperoleh hasil bahwa sebanyak 48 responden mempunyai persepsi kurang sesuai terhadap implementasi pelayanan kesehatan dalam masa pandemik COVID-19 ditinjau dari alat pelindung diri (34,9\%). Sedangkan sebagian besar responden mempunyai gambaran persepsi sesuai terhadap implementasi pelayanan kesehatan dalam masa pandemik COVID-19 ditinjau dari alat pelindung diri, yaitu 59 orang $(55,1 \%)$.

\section{PEMBAHASAN \\ Karakteristik Responden}

Karakteristik responden yang didapat dari hasil penelitian akan menggambarkan pasien yang telah berkunjung ke pelayanan kesehatan selama masa pandemik COVID-19. Berdasarkan hasil penelitian pada variabel karakteristik reponden menunjukkan adanya variasi yang berbeda antar variabel. Pada variabel umur didapatkan umur responden pasien yang berkunjung ke palayanan kesehatan selama masa pandemik COVID-19 mayoritas berumur 12 - 25 tahun. Kelompok umur tersebut termasuk golongan usia produktif yang berpotensi mendapatkan risiko penyakit dari pekerjaan dan daya tahan tubuh. Teori yang dikemukakan Navaro, kelompok umur produktif merupakan umur yang cenderung memanfaakan fasilitas pelayanan kesehatan (Nadia Rahmayanti dan Ariguntar, 2017). Hal ini sesuai dengan penelitian yang dilakukan (Achmad Asnawi, 2009) yang dilakukan di Puskesmas Sukmajaya yang menyatakan $77,3 \%$ pengunjung puskesmas berusia produktif. Menurut jenis kelamin responden diketahui sebagian besar responden pada penelitian ini adalah perempuan sebanyak $73,7 \%$ sedangkan laki-laki sebanyak 24,3\%. Menurut 475 
pennebaker, menyatakan bahwa wanita pada umumnya lebih banyak melaporkan gejala sakit dibandingkan dengan pria (Nadia Rahmayanti dan Ariguntar, 2017). Hal ini juga sesuai dengan penelitian yang dilakukan Achmad Asnawi yang dilakukan di Puskemas Sukmajaya yang menyatakan 60,9\% pengunjung Puskesmas adalah perempuan. Karakteristik responden berdasarkan tingkat pekerjaan adalah Pelajar/Mahasiswa sebanyak 59,55\%. Berdasarkan hal tersebut dapat dilihat bahwa pasien yang berobat merupakan kelompok yang berpendidikan cukup baik. Hal ini sesuai dengan penelitian Achmad Asnawai menyatakan sebagian besar pasien Puskesmas adalah kelompok pekerja tidak tetap sebanyak 58,2\%, yang terdiri dari ibu rumah tangga, pelajar/mahasiswa, buruh dan belum bekerja. Karena kesibukannya, orang yang bekerja seringkali mengabaikan gejala-gejala penyakit. Hal ini diperkuat dengan penelitian yang dilakukan Pennerbaker, yang menyatakan bahwa orang yang tidak bekerja lebih banyak melaporkan gejala penyakit. Berdasarkan hasil penelitian mengenai terakhir pelayanan kesehatan yang dikunjungi pasien selama masa pandemik COVID19 sebagian besar pasien memilih pelayanan klinik dan rumah sakit yaitu masing-masing 34,6\%. Pemilihan fasilitas pelayanan kesehatan dapat dipengaruhi oleh prosedur pelayanan yang cepat (Widianto, 2016).

\section{Persepsi Pencegahan dan Pengendalian Infeksi}

Dalam pelaksanaan pelayanan kesehatan untuk pasien sangat dibutuhkan pelayanan yang baik agar merasa puas, namun tidak semua kepuasan dapat diterima dengan sama karena pasien memiliki persepsi yang berbeda-beda. Persepsi dapat diartikan sebagai proses diterimanya rangsangan melalui panca indera yang didahului oleh perhatian, sehingga individu mampu mengatahui, mengartikan dan menghayati tentang hal yang diamati, baik yang diluar maupun yang ada didalam diri individu tersebut (Haryadi, 2016).

Menurut peneliti, persepsi pasien terhadap implementasi pelayanan kesehatan dalam masa pandemik ini dipengaruhi oleh apa yang pasien lihat dan rasakan pada saat berkunjung ke pelayanan kesehatan lalu terekam dalam ingatan setiap pasien, tidak terbentuk harapan yang lebih terhadap pelayanan kesehatan karena sebagian besar pasien tidak mengetahui standar yang perlu dipenuhi oleh pelayanan kesehatan pada masa pandemik. Sehingga saat pasien mengisi kuesioner penelitian ini dilakukan pengisian dengan benar apa adanya yang terjadi di pelayanan kesehatan yang telah pasien kunjungi.

\section{Pengendalian Teknis}

Pengendalian teknis diperlukan untuk mengisolasi petugas dari bahaya transmisi droplet, yang jika dipersiapkan dengan benar dapat melindungi petugas tanpa merubah atau menambah proses kerja secara signifikan (R. Kemenkes, 2020). Secara umum, persepsi pasien terhadap implementasi pelayanan kesehatan dalam masa pandemik COVID-19 ditinjau dari pengendalian teknis relatif baik. Hasil penelitian menunjukkan sebanyak 52,3\% responden menyatakan persespi sesuai. Hal ini menunjukkan bahwa sebagian besar pelayanan kesehatan di Kota Depok telah sesuai menerapkan pengendalian teknis di pelayanan kesehatan dalam masa pandemik COVID-19. Terbukti dengan hasil jawaban responden, jika dilihat dari masing-masing komponen pengendalian teknis diperoleh jumlah jawaban responden yang menyatakan 
sesuai (sesuai dan sangat sesuai) relatif lebih banyak dibanding yang menyatakan kurang sesuai (sangat tidak sesuai dan tidak sesuai). Berdasarkan Tabel 5.10 sebagian besar responden menjawab Sesuai sebanyak $52,3 \%$ untuk tersedianya posko screening COVID-19 di luar gedung pelayanan kesehatan. Sebagian besar responden menjawab Sesuai sebanyak $47,4 \%$ untuk posko screening diberi atap. Sebagian besar responden menjawab Sangat Sesuai sebanyak $51,4 \%$ untuk physical distancing 1-2meter di setiap ruang tunggu. Dan sebagian besar responden menjawab Sesuai sebanyak 50,5\% untuk tersedianya barrier diloket.

Hal ini sejalan dengan panduan perlindungan di fasilitas pelayanan kesehatan dalam masa pandemik COVID-19. Penularan COVID-19 dapat terjadi melalui kontak dekat dan droplet. Seseorang dapat berisiko jika mereka berhubungan dekat, kontak langsung atau merawat pasien yang terinfeksi. Menurut (PERDOKI, 2020), beberapa pengendalian teknis yang dapat diterapkan untuk mencegah transmisi COVID-19 di pelayanan kesehatan yaitu penyediaan posko screening beratap di luar gedung, tersedianya penghalang fisik (barrier) anatar petugas dan pengunjung utnuk menghalangu semburan droplet. Penghalang fisik dapat dipasang di loket pendaftaran, apotek, loket penerimaan specimen, kasir dan lain sebagainya. Kemudian, terdapat penanda khusus dengan menggunakan lakban/cat/stiker untuk mengatur jarak antar pasien yang datang berkunjung. Penanda khusus dapat dipasang di loket pendafataran, kursi ruang tunggu, ruang pelayanan dan ruang apotek.

\section{Pengendalian Administrasi}

Secara umum, persepsi pasien terhadap implementasi pelayanan kesehatan dalam masa pandemik
COVID-19 ditinjau dari pengendalian adminstratif relatif baik. Hasil penelitian menunjukkan sebanyak $63,6 \%$ responden menyatakan persepsi sesuai. Hal ini menunjukkan sebagian besar pelayanan kesehatan di Kota Depok telah sesuai menerapkan pengendalian administratif di pelayanan kesehatan dalam masa pandemik COVID-19.

$$
\text { Pengendalian administratif }
$$

merupakan kumpulan kebijakan, aturan, atau prosedur untuk mengurangi atau menurunkan paparan transmisi droplet (PERDOKI, 2020). Pengendalian administratif dan kebijakan-kebijakan yang diterapkan meliputi infrastruktur yang berkesinambungan, pembekalan pengetahuan petugas kesehatan, mencegah kepadatan pengunjung di ruang tunggu, mengorganisir pelayanan kesehatan agar persediaan perbekalan digunakan dengan benar, dan pemantauan kepatuhan disertai dengan mekanisme perbaikan yang diperlukan (R. Kemenkes, 2020). Langkah penting dalam pengendalian administratif, meliputi identifikasi dini pasien dengan ISPA/ILI baik ringan maupun berat, diikuti dengan penerapan tindakan pencegahan yang cepat dan tepat.serta pelaksanaan pengendalian sumber infeksi ( $R$. Kemenkes, 2020).

Hal ini berkaitan dengan setiap komponen pengendalian administratif, komponen tersebut merupakan tindakan pencegahan yang setiap pelayanan kesehatan seharusnya lakukan. Dan jika dilihat dari masingmasing komponen pengendalian administratif diperoleh jumlah jawaban responden yang menyatakan sesuai (sesuai dan sangat sesuai) relatif lebih banyak dibanding dengan jawaban kurang sesuai (sangat tidak sesuai dan tidak sesuai). Sebagian besar responden menjawab Sesuai sebanyak $49,5 \%$ untuk pelayanan kesehatan melakukan screening COVID-19 
dengan menggunakan kuesioner. Sebagian besar responden menjawab Sesuai sebanyak 53,3\% untuk pemisahan pasien dengan gejala pernapasan dan pasien tanpa gejala pernapasan. Sebagian besar responden menjawab Sangat Sesuai sebanyak 58,9\% untuk tersedianya poster PHBS, dan sebagian besar responden menjawab Sesuai sebanyak $60,7 \%$ untuk tersedianya poster etika batuk/bersin. Dengan ini hasil gambaran persepsi pasien menunjukkan bahwa secara umum pelayanan kesehatan di Kota Depok telah menerapkan pengendalian administratif dalam masa pandemik COVID-19 dengan sesuai.

\section{APD}

Penggunaan APD merupakan tingkat pengendalian terbawah karena sulit didapat ketika penggunaannya masif, sering tidak tepat pemilihannya dan cara penggunaannya, tidak nyaman sehingga membutuhkan supervisi kepatuhan dan ketepatan penggunaan, serta dalam beberapa hal dapat mempengaruhi proses kerja (PERDOKI, 2020). Hasil penelitian menunjukkan sebanyak 55,1\% responden menyatakan persepsi sesuai. Hal ini menunjukkan sebagian besar pelayanan kesehatan di Kota Depok telah sesuai menerapkan APD dalam masa pandemik COVID-19 terbukti dapat dilihat dari masingmasing komponen APD diperoleh jumlah jawaban responden yang menyatakan sesuai (sesuai dan sangat sesuai) relatif lebih banyak dibanding yang menyatakan kurang sesuai (sangat tidak sesuai dan tidak sesuai). Sebagian besar responden menjawab Sangat Sesuai sebanyak 58,9\% untuk pengunjung pelayanan kesehatan menggunakan masker. Sebagian besar responden menjawab Sangat Sesuai sebanyak $67,3 \%$ untuk seluruh karyawan menggunakan masker. Sebagaian besar responden menjawab
Sangat Sesuai sebanyak 58,9\% untuk petugas kesehatan menggunakan sarung tangan medis. Sebagian besar responden menjawab Sangat Sesuai sebanyak 49,5\% untuk petugas menggunakan goggles. Sebagian besar responden menjawab Sesuai sebanyak 49,5\% untuk petugas kesehatan menggunakan coverall (jubah medis), dan sebagian besar responden menjawab Sesuai sebanyak $52,3 \%$ untuk petugas kesehatan menggunakan sepatu boot.

Pengendalian teknis serta administratif terhadap bahaya transmisi droplet di fasilitas pelayanan kesehatan merupakan bagian yang tidak terpisahkan dengan pemilihan penggunaan alat pelindung diri. Apabila pengendalian teknis dan administratif tidak adekuat menyebabkan APD yang digunakan harus lengkap untuk memberikan proteksi yang maksimal (PERDOKI, 2020). Penggunaan APD yang tidak lengkap tentunya akan sangat mengganggu proses kerja dan cara bekerja termasuk pada saat ketersediaan APD yang semakin sulit didapatkan pada saat terjadi pandemik.

\section{KESIMPULAN}

Berdasarkan hasil penelitian yang telah dilakukan di Kota Depok dan pembahasan diatas, maka peneliti dapat menarik kesimpulan, bahwa:

1. Pelayanan kesehatan yang terakhir dikunjungi responden sebelum dilakukan pengisian kuesioner, didapatkan sebagian besar responden mengunjungi klinik dan rumah sakit sebanyak $34,6 \%$.

2. Didapatkan sebagian besar responden atau 52,3\% memiliki persespi bahwa penerapan pengendalian teknis di pelayanan kesehatan wilayah Kota Depok sudah sesuai.

3. Didapatkan sebagian besar responden atau $63,6 \%$ memiliki 
persepsi bahwa penerapan pengendalian administratif di pelayanan kesehatan wilayah Kota Depok sudah sesuai.

4. Didapatkan sebagian besar responden atau 55,1\% memiliki persepsi bahwa penerapan APD di pelayanan kesehatan wilayah Kota Depok sudah sesuai.

\section{SARAN}

Untuk Pelayanan Kesehatan dapat mempertahankan penerapan pengendalian teknis dengan lebih memperhatikan kualitas posko screening, selalu ada penanda atau barrier untuk penerapan physical distancing sehingga pelayanan kesehatan tetap menjadi tempat yang aman. Dapat melaksanakan program pencegahan dan pengendalian infeksi khususnya dalam masa pandemik secara konsisten sesuai dengan pedoman, dilakukan evaluasi secara berkelanjutan terhadap pengendalian teknis, pengendalian administratif dan APD, sehingga pasien dapat puas dan merasa aman untuk berkunjung ke pelayanan kesehatan terkait.

\section{DAFTAR PUSTAKA}

Achmad, A. (2009). Gambaran Persepsi Pasien terhadap Pelayanan Kesehatan di Puskesmas Sukmajaya Kota Depok Tahun 2009. Universitas Indonesia.

Bnpb, K., Adisasmito, W., Guru, P. D., Fkm, B., \& Indonesia, U. (2020). Gugus tugas percepatan penanganan covid-19 1. 1-39.

Depok, K. (2020). Kota Depok I Covid19.

Haryadi. (2016). Analisis Persepsi Mutu Pelayanan Terhadap Kepuasan Pasien di Ruang Rawat Inap RSUD Langsa. USU.

Kemenkes, C., \& Ke-, R. (2020). Pedoman pencegahan dan pengendalian coronavirus disease (covid-19) revisi ke-4 1.

Kemenkes, R. (2020). Pedoman Pencegahan dan Pengendalian COVID-19. Pedoman Kesiapan Menghadapi COVID-19, 0-115.

Nadia Rahmayanti, S., \& Ariguntar, T. (2017). Karakteristik Responden dalam Penggunaan Jaminan Kesehatan Pada Era BPJS di Puskesmas Cisoka Kabupaten Tangerang Januari-Agustus 2015. Jurnal Medicoeticolegal Dan Manajemen Rumah Sakit 10.18196/Jmmr.2016, 6(1), 6165.

https://doi.org/10.18196/jmmr.6 128

PERDOKI, Spesialis, P., \& Okupasi, K. (2020). DI FASILITAS PELAYANAN KESEHATAN DALAM MASA PANDEMI COVID-19 DALAM MASA PANDEMI COVID-19 Perhimpunan Spesialis Kedokteran Okupasi Indonesia. (April).

Riyanto, Slamet, \& Adhita, A. (2020). Metode Riset Penelitian Kuantitatif Di Bidang Manajemen, Teknik, Pendidikan Dan Eksperimen. Yogyakarta: Deepublish.

Tim Kerja Kementerian Dalam Negeri. (2020). Pedoman Umum Menghadapi Pandemi Covid-19 Bagi Pemerintah Daerah : Pencegahan, Pengendalian, Diagnosis dan Manajemen. Journal of Chemical Information and Modeling, 53(9), 1689-1699. https://doi.org/10.1017/CB09781 107415324.004

WHO. (2020). Coronavirus Disease 2019 (COVID-19) Situatuion Report.

Widianto, A. A. K. (2016). Alasan Pasien Memilih Jasa Pelayanan Kesehatan di Rumah Sakit Bersalin Fr. Dewi Isbat Indarni, S.St. Universitas Sanata Dharma. 